\title{
THE CENTRE OF EXCELLENCE FOR TRANSPORT SERVICE AND CONTROL
}

The Centre of Excellence at the University of Zilina was established in 2009 as a new approach to research supported by EU. This model has been acknowledged around the EU as a highly effective way to strengthen a country's research capacity, build partnerships and translate discoveries and advances into economic prosperity and a better quality of life for all citizens. The Centre of Excellence for transport service and control at the Faculty of Operation and Economics of Transport and Communications at the Department of Road and Urban Transport consists of the laboratory of transport service, laboratory of mass passenger transport control and laboratory of freight transport. The main objectives of these laboratories are presented in this article.

Keywords: excellence, laboratory, intelligent transport system, passenger transport, freight transport, transport service.

\section{Introduction}

A Centre of Excellence is a formalized and documented relationship between Education and Research, the educational institution and the third party. All parties involved in the Centre of Excellence will bring to the partnership a special expertise of strategic importance to transport. A Centre of Excellence can represent either a physical place on the campus of an educational institution. In our case the main topics are defined in the area of intelligent transport systems (ITS) in road and urban transport. In the Centre of Excellence students, transport providers, research workers and scientists will be able to find a selection of ITS-solutions that ease and facilitate our daily lives. Intelligent transportation system has become essential instrument to increase safety and security on the road network, streamline logistics and reduce environmental effects caused by transport. For the educational institution it is very important to create an excellent workplace for R\&D systems and intelligent transport services provided as basic infrastructure development companies using technology knowledge.

\section{The Centre of Excellence at the Department of Road and Urban Transport}

The strategic objective of the Centre of Excellence is in line with the main objective of the call OPVaV-2008/2.1/01-SORO "Operational Research and Development Program - Support networks of excellent research and development departments as pillars of regional development and promotion of regional cooperation". With a focus on technology, industry, or community, the Centre of Excellence will draw upon the expertise of the partners involved to showcase groundbreaking activities and to promote transport technologies. Intelligent transport is an interdisciplinary problem. Creating the Centre of Excellence is intended to integrate research and teaching staff. The aim is to promote research of high additional value. Some institutes carry out research with end users who will ultimately benefit from its application. This is our interest as well. It can result in the higher level of collaboration between university researchers, graduate students, industry and public sector institutions.

Our research and development program and innovation will help to:

- Clarify innovation plans and medium-term challenges.

- Assemble partners and resources to develop solutions.

- Build collaborative R\&D teams to develop technology.

- Access early-stage commercialization support.

- Engage students as future employees to build higher level organization.

The Centre can act as a bridge between transport research, transport companies and regional transport boards to conduct transport studies. It can develop a new model for commercializing university research as well. Put simply, the Centre can help transport companies, councils and their partners to deliver better services by supporting them in their efforts to become more efficient, innovative and engaged with citizens. We develop the team - partners and resources - required to deliver innovative solutions. The Centre is able to offer a wealth of expertise and experience.

\section{The Centre offers:}

- Access to research capabilities including facilities, equipment, personnel and experienced research teams.

\footnotetext{
* Jozef Gnap, Alica Kalasova, Marian Gogola, Jan Ondrus

Faculty of Operation and Economics of Transport and Communications, University of Zilina, Slovakia,

E-mail: jozef.gnap@fpedas.uniza.sk
} 
- Creative students trained in leading-edge knowledge and technology areas.

- Opportunities to participate in a broad range of research initiatives including consortia and collaborative projects.

- Extensive intellectual property and project-management expertise.

\section{Laboratory of Transport Service}

The strategic objective of the project is to create an excellent laboratory for intelligent transport services as a precondition for infrastructure development companies using technology knowledge.

Movement and its quality is one of the key elements for assessing the standard of living. At the beginning of the 21st. century, our society can not avoid the trends of development in information society, which has a large impact on the transport process. Almost each step of life of our citizens depends on the quality of this service.

It is now necessary to:

- improve road safety and protection of all its users,

- avoid creating congestion,

- reduce the degradation of public transport

- reduce the negative impact on the environment,

- ensure that citizens of the Slovak Republic have access to safe and affordable transport.

The use of new technologies is an essential prerequisite for the introduction of advanced applications to address current traffic problems. Intelligent transport systems are sophisticated multimodal tools that integrate advanced technologies and apply them in transport in order to develop solutions to improve the quality of life for all citizens of Slovakia. The applications help to improve living conditions of the inhabitants, increase time and finance savings in the economic activities of the company, and improve the environment.

The main objectives of transport telematics are to offer to traffic users intelligent services, which must be considered at several levels: - Services to passengers and drivers (users) - information presented to drivers via information systems on motorways, information sent to drivers to their cars (dynamic navigation), etc.

- Services for infrastructure administrators (administrators of transport roads, administrators terminals) - management of transport infrastructure maintenance, monitoring and management of traffic safety in relation to the economics of traffic routes, etc.

- Services for transport operators (carriers) - selection of traffic routes and most expedient routes, management of vehicle fleet circulation, etc.

- Services for public administration - linking the systems of transport telematics to information systems of public administration, monitoring an assessment of passenger and freight transport, solution of transport infrastructure finance, instruments for execution of transport policy of cities, regions, state.
- Services for security and rescue system - interconnection of the systems of transport telematics with integrated rescue system and security systems of the state, provision of better organization of interventions in liquidation of failures, accidents, enhancement of prevention from occurrence of incidents with ecological consequences.

- Services for financial and control institutions - electronic identification of vehicles and freights, monitoring of and search for stolen vehicles, electronic payments for provided ITS services.

A result of the conceptual interconnection of particular subsystems of transport telematics is the information superstructure over transport, enabling to implement the same management tools for this network sector, like it is today with the management of manufacturing enterprises (monitoring of costs, establishment of separate economic units etc.)

Knowledge of economic processes related to transport will enable execution of the state transport policy and offer a purposeful investment strategy in this branch. This concept of transport telematics can offer clear, controllable and transparent rules for entry of private investors in transport infrastructure (including the own funds of transport telematics).

The basic technologies of transport telematic systems include the following fields, for example:

- Electronic payments - payment for ITS services, for use of infrastructure, means of transport.

- Management of security and rescue measures - management of rescue and security vehicles, monitoring of dangerous freights.

- Management of traffic processes - traffic planning, traffic management, management of transport infrastructure maintenance.

- Management of public passenger transport - integrated transport systems, state administration.

- etc.

Research on intelligent infrastructure systems is linked very closely; every part of it is interactive and conditional. To enable the project to be realized, we need not just the sufficient scientific and research capacities in human resources, but also the instrumentation appropriate to those of current global requirements for research in abovementioned area.

Procured instrumentation will be used to monitor some of the factors that will determine and affect the functioning of intelligent infrastructure systems. By the implementation of this activity, a department of research and development services will achieve the construction place in the area of intelligent infrastructure. The department receives additional opportunities for collaboration or integration into the research grant programs.

\section{Laboratory of Mass Passenger Transport Control}

The current status of Mass Passenger Transport (MPT) and in general Public Transport (PT) is characterized by decreasing level of ridership. The MPT has to face problems with the moving of 
passengers to the individual car transport. A big challenge for MPT consists in the process of implementation of new technologies which can help in the field of operation, management and service. Then the results can be applicable in order to improve the quality of provided service, better operational and management control, etc. The main advantage of the Laboratory of Mass Passenger Transport Control consists in the development of technological environment that can substitute real conditions in order to test, implement and develop various applications and methods for making the service and operation of public transport easier and more qualitative.

The goal is to equip the laboratory with modern technologies allowing the development of rich and useful applications in the field of public transport. At the present time the laboratory has a technology which is focused on passenger and vehicle fare information data and ticket processing.

Therefore, the laboratory will deal with the following research topics:

\section{Fleet management control}

This research topic deals with the area of fleet management control where various applications will be tested. This topic includes: - Effective, consistent real time traffic management service delivery.

- Safe and secure public transport facilities.

- Timely and effective public transport vehicle operations continuity.

- Efficient centre management service delivery.

- Modelling the operation of vehicles.

- Vehicle tracking.

- Vehicle route optimization.

- Analyzing the impact of various traffic conditions, etc.

This topic has a big potential to be an interesting tools for public transport operators. For example, the applications analyze GPS data streams in real time to help fleet managers identify high risk driving behaviour and lower fleet operating costs resulting from excessive speeding. The applications can track and monitor the position and operation of fleet vehicles, giving fleet managers unprecedented visibility into operations delivering cost-saving efficiencies such as real-time GPS tracking of vehicles from the desktop, automatic route optimization, and detailed reporting for advanced decision support and efficient regulatory compliance.

With this application, the dispatchers and managers can view real-time information and summary of data in centre displays to support rapid, optimal decision making for most productive use of vehicles and drivers. These dashboards can drill down and include information customized to the needs of individual users.

\section{Passenger's information system}

The information in public transport is an essential for passenger. The common standard of static bus top information doesn't meet the requirements for actual and real time information in the technological highly depended society. One goal of our laboratory will be to test the new form of the information providing regard- ing to the public transport service. Not only in direction from PT operators to passengers, but also from passengers to operators.

\section{Passenger service}

This topic includes analyzing and testing various technologies which are suitable for passenger processing as types of tickets, types of passengers. The passengers use the modern technologies that allow the information sharing about them and that is the reason for implementing such technologies into the passenger service.

The laboratory will also serve as virtual PT operation centre where following research topics will be included:

- Data processing.

- Passenger information systems in stops, vehicles.

- Booking systems for mass passenger transport, taxi.

- Passenger time schedule information PDZ, RDS-TMC.

- Solving static transport, parking.

- Providing information via internet, mobile phones and etc.

- Demand responsive service.

- New types of passenger processing.

- The results can be applied in ecological issues, sustainable mobility.

- Forecasting future travel demand.

- Tariff testing.

- Virtual public transport network.

- Applying geographic information systems.

\section{Laboratory of Freight Transport}

This laboratory will cover the three main areas of freight transport:

\section{Load securing}

This research activity will contribute to the transport safety within load securing during the carriage. The aim is to provide load securing instructions and certificates about safe load securing with big influence on traffic safety within the national and European level. Many manufacturers export their goods from Slovakia abroad. There is no such a laboratory in Slovakia but there are manufacturers of load securing equipment both in Slovakia and in Zilina. The testing of vehicle superstructures for load securing is also missing and majority of superstructures produced in Slovakia does not have any load security testing.

Following research areas will be covered by these facilities:

- testing of package stability for surface transport (road, rail, water) - Fig.1,

- strength testing of lashing bands, straps, chains, steel ropes (EN 12195-2, 3, 4) - Fig.2,

- static and dynamic load securing tests and identification of wrong load securing (traffic safety),

- static and dynamic tests for friction coefficients in laboratory conditions and in practice - Fig.3,

- monitoring of inertia forces inside cargo transport units (vehicle, wagon, container) during real carriages, 
- analysis of load damages rising from insufficient packaging and load securing.

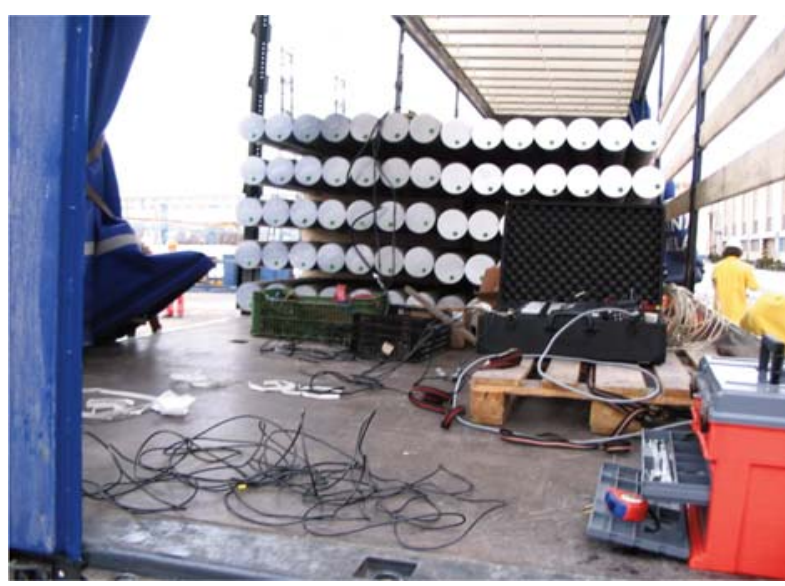

Fig. 1 Dynamic test of package stability

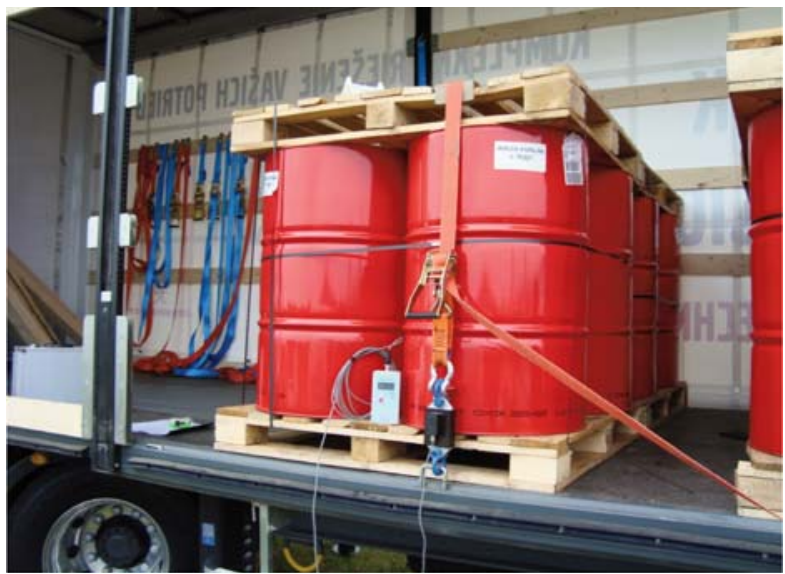

Fig. 2 Strength test of lashing bands

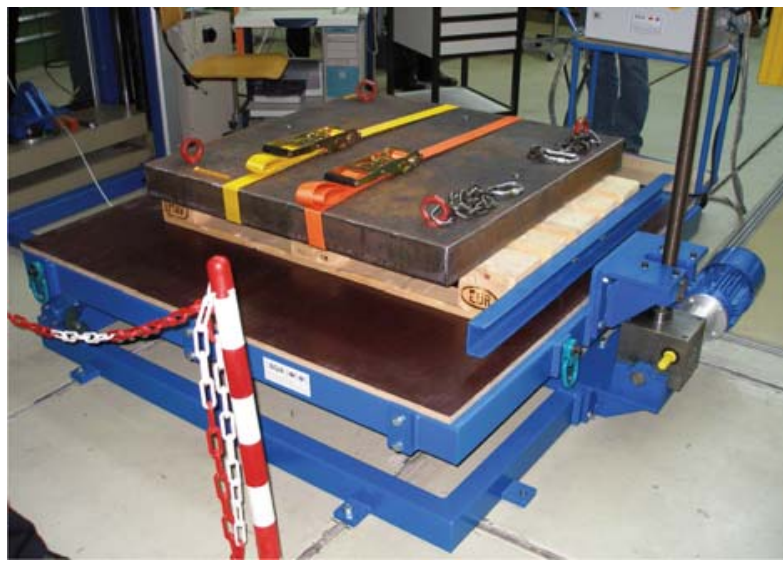

Fig. 3 Test for friction coefficients in laboratory in Germany

Quality and safety of transport service

Measurements, monitoring and evaluation of basic transport parameters during the carriage and storage in warehouses and logistic centres is covered by these activities in accordance with ATP agreement, laws and regulations and customer requirements. Following equipment will perform these activities:

- 3-axes acceleration sensor,

- 1-axis acceleration sensor,

- temperature sensor,

- pressure sensor,

- humidity sensor,

- tilt and roll sensor,

- position sensor (GPS),

- remote on-line communication with monitoring device.

Testing of control recording equipment (tachographs) and information technology in transport

The laboratory will test recording equipment and assess their compliance with legislation. The laboratory will further evaluate the possibility of using tachographs recorded data for management and monitoring of road transport and improve safety and transport services. In practice, we encounter the fact that not all possibilities of digital tachographs are actually used for fleet management. However, digital tachographs recorded in real time large amounts of information [20].

The aim of the laboratory would also be evaluation of information technology used in road transport. On the market there are a number of information technology and software which do not provide appropriate information for management of road transport. The laboratory will process the requests for upgrading the analyzed technology to the most streamline operation in transport services.

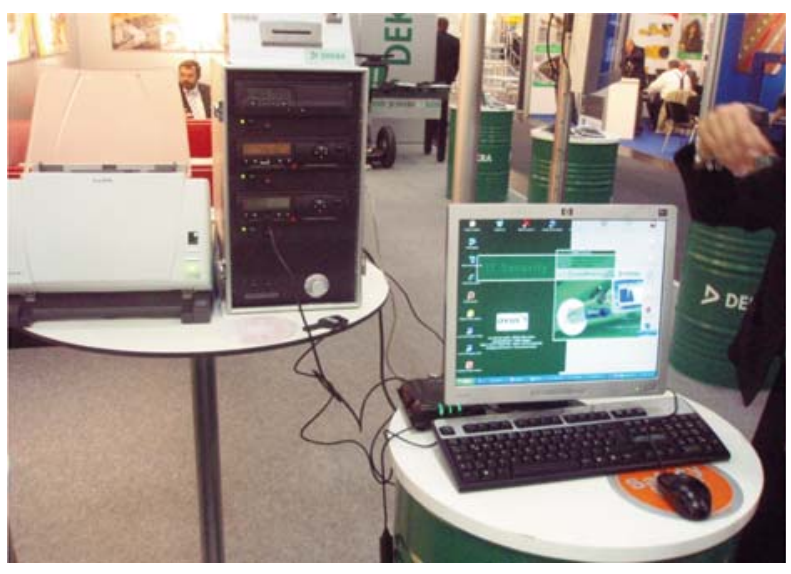

Fig. 4 Workplace for testing digital tachographs (example from DEKRA company)

\section{Conclusion}

It must be appreciated that the EU Structural Funds will be available for building excellent laboratories. The laboratories will be very useful not only for research and development activities but also for raising the level of knowledge and practice of students of all university degrees in transport control and transport services. 
Acknowledgement:

This contribution is the result of the project implementation:

Centre of excellence for systems and services of intelligent trans- port, ITMS 26220120028 supported by the Research \& Development Operational Programme funded by the ERDF.

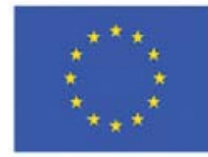

Európska únia

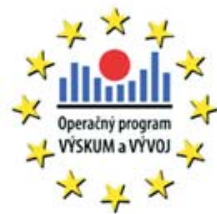

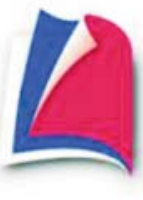

Agentúra

Ministerstva školstva, vedy, výskumu a športu SR pre štrukturálne fondy EÚ

"Podporujeme vyskumne aktivity na Slovensku/Projekt je spolufinancovany zo zdrojov EU."

\section{References}

[1] BANISTER, D.: Transport Planning, University College London, 2002, 2nd edition, 2007. ISBN 0415261724.

[2] COLEMAN, A.F.: Transport Planning and Traffic Engineering. Ed. Heinemann, 1996, ISBN 978-0-340-66279-3.

[3] KRIVDA, V., OLIVKOVA, I., PALO, J., RICHTAR, M.: Transport Telematics. Published by EDIS ZU in Zilina, 2009, ISBN 97880-8070-981-5.

[4] SCHLOSSER, T.: Intelligent Transport Systems, 2001, ISBN 80-88905-64-8.

[5] SVITEK, M.: Telematic Services Connected with the Electronic Toll System. Technologies \& Prosperity, Praha 2006, ISSN $1213-7162$.

[6] JAGELCAK, J., GNAP, J.: The Instructions for Securing of Goods in Freight Road Transport. PROFITUBE s.r.o. Kosice, University of Zilina, Zilina, 2007.

[7] JAGELCAK, J., GNAP, J.: The Instructions for Securing of Goods in Freight Road Transport SLOVALCO a.s., ZU v Ziline, Zilina, 2007.

[8] JAGELCAK, J., GNAP, J.: The Instructions for Securing of Goods in Freight Road Transport. DUSLO a.s., ZU v Ziline, ZU, 2007.

[9] IMO/ILO/UN ECE Guidelines for Packing of Cargo Transport Units (CTUs), International Maritime Organization, London, 1997, ISBN 92-801-1443-3.

[10] Safe Packing of Cargo Transport Units (CTUs) - COURSE, Model course 3.18, International Maritime Organization, London, 2001, ISBN 92-801-5116-9.

[11] Safe Packing of Cargo Transport Units (CTUs) - WORKING BOOK with quick lashing guides for transport on road and in sea areas A, B, \& C, Model course 3.18, International Maritime Organization, London, 2001, ISBN 92-801-5127-4.

[12] JAGELCAK, J.: Verification Measurements of Frequent Lashing Methods and Load Distribution Diagram [on-line] - Version 2.2. Zilina, (C) Juraj Jagelcak, 2006, p. 59 <http://kcmd.uniza.sk/securing/securingSKEN.pdf〉.

[13] ANDERSSON, P., JAGELCAK, J., LIND, E., PETERSEN, S.S.: Report from Pulling Tests with Used Lashing Equipment [on-line], [Hoganas: MariTerm AB], 2009. <http://www.mariterm.se/hoganas/rapporter.html>.

[14] JAGELCAK, J., RIEVAJ, V.: Standard Tension Force: Tension Forces in Web-lashing for Load Securing Created by a Ratchet Tensioner [1st ed.]. Koln: Lambert Academic Publishing AG \& Co. KG, 2009. ISBN 978-3-8383-1817-2.

[15] JAGELCAK, J.: Tension Forces in Web-lashing for Load Securing. In: CMDTUR 2009 [electronic source]: Proc. of 5th int. conference : Zilina, Slovakia, 2009, Zilinska univerzita, EDIS ZU, 2009. ISBN 978-80-554-0124-9, pp. 70-74, CD-ROM.

[16] EN 12195-2 Load Restraint Assemblies on Road Vehicles. Safety. Part : Web Lashing Made from Man-made Fibres.

[17] EN 12195-3 Load Restraint Assemblies on Road Vehicles. Safety. Part 3: Lashing Chains.

[18] EN 12195-4 Load Restraint Assemblies on Road Vehicles. Safety. Part 4: Lashing Steel Wire RSopes.

[19] European Best Practice Guidelines on Cargo Securing for Road Transport [on-line], [Andersson, P. ... et al.]. Online document. [Brussels: European Commission, Directorate-General for Energy and Transport], 2006. p. 208, <http://ec.europa.eu/ transport/road_safety/ vehicles/doc/cargo_securing_guidelines_en.pdf>

[Coauthors: Arbaiza, Alberto; Bonnet, Geraldine; Charalampopoulos, George; Finn Engelbrecht, Ruby; Hassing, Sibrand; Jagelcak, Juraj; Jonckheere, Filip; Kolettas, Soteris; Kuusk, Harri; Karki, Esko; Linssen, Hubert; Lundqvist, Anders; Manolatou, Eleni; Martins, Joao; Nordstrom, Rolf; Pompe, Julie; Prochazka, Milos; Renier, Luc; Rocco, Luca; Rolland, Nathalie; Ruzgus, Gintautas; Schoofs, Cyriel; Siegmann, Ernst Otto; Surmont, Charles; Vaikmaa, Siim; Vaituzs, Zulizs; Van Praet, Willy; Verlinden, Jos; Wiltzius, Marc; Winkelbauer, Martin]

[20] POLIAK, M., GNAP, J.: The Wwork of Drivers of Freight Vehicles and Buses and Usage of the Tachographs - extended and updated version to 1st. 2. 2009; Zilinska univerzita: EDIS - ZU, Zilina, 2009; ISBN 978-80-7100-989-1. 